\title{
37. CAROTENOID DIAGENESIS IN PLEISTOCENE TO MIOCENE SEDIMENTS FROM THE PERU MARGIN1
}

\author{
Daniel J. Repeta ${ }^{2}$
}

\begin{abstract}
The quantitative distribution of carotenoids in sediments of Pleistocene to Miocene age from the Peru upwelling area is reported. Major pigments include $\beta$-carotene, diatoxanthin, caroteno-3,3'-diols from phytoplankton, astaxanthin and canthaxanthin from crustaceans, and spheroidenone from bacteria. $\beta$-carotene epoxides are major consituents, representing transformation products in the degradation of $\beta$-carotene to low molecular weight compounds. The absolute abundance of carotenoids reflects bottom-water oxicity at the time of deposition; highest concentrations of carotenoids were observed in laminated muds deposited within the oxygen-minimum zone, with reduced or negligible concentrations of pigments observed in bioturbated sequences deposited during periods of well-oxygenated bottom water. $\beta$-carotene, the most abundant pigment in recently deposited sediments, slowly degrades through a sequence of transformation reactions initiated by epoxidation. The $4,4^{\prime}$ dioxo-carotenoids, which are unable to form 5,6-epoxides, have been preferentially preserved in these sediments.
\end{abstract}

\section{INTRODUCTION}

Carotenoids are highly unsaturated tetraterpenoids that function as photosynthetic accessory pigments in all species of marine algae. The structures of more than 400 carotenoids have been reported; however, the distribution of specific pigments is often restricted to one or only a few classes of organisms. In principal, the diversity of structures and the highly restricted distribution of specific carotenoids make them excellent biomarkers for determining the sources of organic matter in marine sediments. These characteristics were recognized by organic geochemists as early as 1930 , and the distribution of carotenoids in a suite of lacustrine and marine sediments has since been reported (early studies summarized by Schwendinger, 1969; Watts and Maxwell, 1977; Cardoso et al., 1978; , Louda and Baker, 1981; Boon et al., 1983; Ridout et al., 1984; Repeta and Gagosian, 1987; Repeta, 1989).

The distribution of carotenoids in surface sediments is different from marine algae, making semiquantitative assessments of algal influxes to ancient sediments difficult or impossible. A better understanding of the transformation processes that degrade carotenoids is needed to use these compounds as proxies for algal biomass when interpreting the record of paleo-upwelling conditions preserved in cores from Ocean Drilling Program (ODP) Leg 112. Rapid diagenetic reactions alter the original (algal) pigment distribution to a complex suite of transformation products. Although diatoms are known to be a major contributor of organic matter in the Peru upwelling region, carotenoids characteristic of these organisms occur only at low concentrations in surface sediments (Ridout et al., 1984; Repeta and Gagosian, 1987). Watts and Maxwell (1977) and Baker and Louda (1982) previously reported the distribution of carotenoids in sediments deposited 0.3 Ma from the Cariaco Trench and Gulf of California, respectively. Watts and Maxwell (1977) provided evidence for the slow saturation of carotenoids, a transformation pathway

\footnotetext{
${ }^{1}$ Suess, E., von Huene, R., et al., 1990. Proc. ODP, Sci. Results, 112. College Station, TX (Ocean Drilling Program).

2 Department of Chemistry, Woods Hole Oceanographic Institution, Woods Hole, MA 02543 .
}

that would yield the fully saturated carotenes reported in ancient sediments (Murphy et al., 1967; Kimble et al., 1974). Baker and Louda (1982) observed the post-depositional formation of $\beta$-carotene epoxides, which is confirmed by the results presented here.

Repeta (1989) proposed a diagenetic pathway for most major phytoplankton carotenoids, which offered a quantitative explanation for the distribution of carotenoids in recently deposited anoxic marine sediments. Under this scheme, caroteno-5,6-epoxides undergo rapid rearrangement and fragmentation to loliolide. Carotenoids having $\beta$-cyclic endgroups undergo an additional, initial epoxidation step to yield isololiolide, loliolide, and dihydroactinidiolide upon fragmentation. Acyclic, aromatic, 4-oxo, and $\left(5,5^{\prime}, 6,6^{\prime}\right)$-diacetylenic carotenoids cannot be degraded by this pathway and should be preferentially preserved in sediments. This scheme suggests that the complex mixture of carotenoids extant in surface sediments of the Peru margin should be reduced to a simple mixture of $4,4^{\prime}$-dioxo, acyclic, and diacetylenic pigments over time. Aromatic carotenoids have not been identified in Peru sediments. We report here the results from our analysis of three cores recovered during Leg 112 (Sites 679, 681 , and 684) that test this hypothesis. Our results demonstrate that the complex mixture of carotenoids in surface sediments is indeed reduced to a simple suite of $4,4^{\prime}$-dioxo and acyclic pigments. However, the rate of degradation for $\beta$ carotene is somewhat slower than expected.

\section{METHODS}

Samples were stored frozen at $-40^{\circ}$ until analyzed. Freshly thawed sediment (1-19 g) was ultrasonically extracted in methanol $\left(3 \times, 20 \mathrm{~cm}^{3}\right.$ each) and methylene chloride $(3 \times, 20$ $\mathrm{cm}^{3}$ each). The combined extracts were evaporated under reduced pressure to approximately $1 \mathrm{~cm}^{3}$ and the pigments redissolved by adding $2 \mathrm{~cm}^{3}$ of acetone/water $(1: 1, \mathrm{vol} / \mathrm{vol})$. Carotenoids were purified by passing the concentrate $\left(3 \mathrm{~cm}^{3}\right)$ through a C-18 Sep-Pack (Waters Assoc., Milford, MA) followed by a $2-\mathrm{cm}^{3}$ distilled/water wash. Pigments were recovered by rinsing the Sep-Pack with $4 \mathrm{~cm}^{3}$ of acetone. The acetone eluate was evaporated to dryness, redissolved in 1 $\mathrm{cm}^{3}$ tetrahydrofuran (THF) and applied to a $1 \times 30 \mathrm{~cm}$ column prepacked in THF with polystyrene gel prepared according to 
Table 1. Location data for piston core samples from Holes $679 \mathrm{C}, 681 \mathrm{C}$, and 684C.

\begin{tabular}{cc}
\hline $\begin{array}{c}\text { Core, section, } \\
\text { interval (cm) }\end{array}$ & $\begin{array}{c}\text { Dry weight } \\
(\mathrm{g})\end{array}$ \\
\hline $112-679 \mathrm{C}-2 \mathrm{H}-5,11-12$ & 3.94 \\
$3 \mathrm{H}-6,3-4$ & 6.18 \\
$4 \mathrm{H}-6,54-55$ & 6.03 \\
$5 \mathrm{H}-1,104-105$ & 6.40 \\
$6 \mathrm{H}-1,32-33$ & 1.47 \\
$7 \mathrm{H}-2,116-117$ & 5.48 \\
$8 \mathrm{H}-1,12-13$ & 5.58 \\
$112-681 \mathrm{C}-1 \mathrm{H}-3,11-11.5$ & 1.11 \\
$2 \mathrm{H}-5,103-103.5$ & 0.92 \\
$3 \mathrm{H}-6,17.5-18.0$ & 1.46 \\
$4 \mathrm{H}-2,110-110.5$ & 0.76 \\
$5 \mathrm{H}-2,50-50.5$ & 2.45 \\
$7 \mathrm{H}-2,40-40.5$ & \\
$9 \mathrm{H}-4,21-21.5$ & 7.59 \\
$10 \mathrm{H}-3,0-0.5$ & 2.16 \\
$112-684 \mathrm{C}-1 \mathrm{H}-3,50-51$ & 2.01 \\
$12 \mathrm{X}-2,21-27$ & 3.03 \\
\hline
\end{tabular}

Moore (1964). Elution with THF yields a carotenoid fraction substantially free of chlorines and porphyrins.

Separation of individual carotenoids was achieved by high pressure liquid chromatography (HPLC) of the carotenoid fraction using a $3.9 \times 150 \mathrm{~mm}$ Adsorbosphere $3 \mu \mathrm{m}$ octadecylsily bonded silica column eluted with a linear gradient of $20 / 800.5 \mathrm{M} \mathrm{NH}_{4} \mathrm{OAc}(\mathrm{aq}) / \mathrm{methanol}$ ( $\mathrm{vol} / \mathrm{vol}$ ) to $20 / 80$ acetone/ methanol (vol/vol) for $20 \mathrm{~min}$. The carotenols lutein and zeaxanthin are only partially resolved under the chromatographic conditions used for separation of the samples. Therefore, unambiguous identification of this component cannot be made and is hereafter referred to as zeaxanthin/lutein. Visible spectra were collected by an online diode array detector (Waters Model 990) between 350 to $800 \mathrm{~nm}$ with a $3 \mathrm{~nm}$ bandpass. Astaxanthin, canthaxanthin, and $\beta$-carotene were identified by co-injection and comparison of visible and mass spectra with authentic compounds. Spheroidenone, zeaxanthin/lutein, diatoxanthin, and $\beta$-carotene epoxides were identified by mass and visible spectra alone.

$\beta$-carotene, astaxanthin, and canthaxanthin were quantified by preparing standard solutions of the pure compounds in acetone and by measuring the absorbance of $\lambda_{\max }$ (Varian dual-beam 200 DMS spectrophotometer). Extinction coefficients used are $139,000 \mathrm{~cm}^{3} / \mathrm{mol} \mathrm{cm}$ for $\beta$-carotene and 100,000 $\mathrm{cm}^{3} / \mathrm{mol} \mathrm{cm}$ for all other pigments. Aliquots of the standard solutions were then analyzed by HPLC under the conditions used for sediment extracts. Peak areas were integrated from reconstructed chromatograms at $440 \mathrm{~nm}$.

\section{RESULTS AND DISCUSSION}

Sample descriptions and concentration data for major carotenoids are given in Tables 1 and 2, respectively. The carotenoid distribution in Pleistocene sediments of all three cores analyzed is similar, with contributions from diatoms ( $\beta$-carotene, zeaxanthin/lutein, diatoxanthin) crustaceans (astaxanthin, canthaxanthin), and purple nonsulfur photosynthetic bacteria (spheroidenone, acyclic carotenoids) (Fig. 1), Sediment trap studies (Repeta and Gagosian, 1984) and analyses of surficial sediments (Ridout et al., 1984; Repeta 1989) underlying the contemporary upwelling area demonstrate that fucoxanthin and diadinoxanthin are the major carotenoid pigments deposited in this region, accounting for $>70 \%$ of the original carotenoid influx. Fucoxanthin has been rapidly degraded in the upper 2 to $4 \mathrm{~cm}$ of recent sediments; however, the concentrations of $\beta$-carotene and diatoxanthin remain relatively constant. $\beta$-carotene is the most abundant carotenoid in recent sediments from the three sites analyzed in the present study, with concentrations of 30 to $57 \mu \mathrm{g} / \mathrm{g}$ dry weight sediment ( $g d w)$. These concentrations are within the range of previously observed values for surface sediments $(0-20 \mathrm{~cm})$ collected at the landward edge of the Peru upwelling system in $110 \mathrm{~m}$ of water at $15^{\circ} \mathrm{S}(24-60 \mu \mathrm{g} / \mathrm{gdw}$, $4 \%$ organic carbon), but below the levels for surface sediments $(0-6 \mathrm{~cm})$ collected near the center of the upwelling system in $255 \mathrm{~m}$ of water at $11^{\circ} \mathrm{S}(187-304 \mu \mathrm{g} / \mathrm{gdw}, 20 \%$ organic carbon) (Repeta, 1989).

Sediments from Hole $679 \mathrm{C}$ were deposited in $450 \mathrm{~m}$ of water at the seaward edge of the contemporary upwelling system. Sixteen carotenoids were isolated from a mixture containing more than 40 pigments in the youngest sediments analyzed at this site. Of these, nine could be obtained in sufficient quantity and purity for mass spectrometric analysis (Table 3). All-trans $\beta$-carotene and a series of cis isomers are the most abundant pigments in samples to $40 \mathrm{~m}$ below the sea floor (mbsf) (Fig. 2). Major phytoplankton xanthophylls characteristic of marine diatoms are absent, or present only in trace quantities in the sample, and only diatoxanthin and zeaxanthin/lutein could be identified. Other xanthophylls present in low abundance include astaxanthin, canthaxanthin, major pigments of zooplanktonic crustaceans, and spheroidenone, characteristic of nonsulfur photosynthetic bacteria. The concentration of $\beta$-carotene decreases downcore, from 28 to $30 \mu \mathrm{g} / \mathrm{gdw}$ in recent sediments, to $13 \mu \mathrm{g} / \mathrm{gdw}$ in Miocene sediments at $66 \mathrm{mbsf}$. Over this same interval, the concentration of phytoplankton xanthophylls decreases to nondetectable levels. In Miocene sediments (Cores $112-679 \mathrm{C}-6 \mathrm{H}$ to $-8 \mathrm{H}$ ) the concentration of $\beta$-carotene has decreased to below the level of 4,4'-dioxo-carotenoids. No significant decrease in the concentration of $4,4^{\prime}$-dioxo-carotenoids was observed downcore (Fig. 3). Astaxanthin and canthaxanthin are incorporated in hard-tissue components of crustaceans, and their preservation may result from the long-term resistance of this material to degradation. However, as discussed below, our data suggest that selective preservation because of molecular structure may be important.

The sediments analyzed from Hole $681 \mathrm{C}$ represent two distinct depositional environments: lithologic Unit I (Cores $112-681 \mathrm{C}-1 \mathrm{H}$ to $-4 \mathrm{H}$ ) of Holocene-Pleistocene age, consists of a partially laminated, diatomaceous mud to diatom ooze, and Unit II (Cores 112-681C-5H to -1OH) of Pleistocene age representing sediments deposited during periods of elevated oxygen levels in bottom water, as evidenced by extensive bioturbation and lower total organic carbon contents. Solventextracted sediments from Unit I and Core $112-681 \mathrm{C}-10 \mathrm{H}$ are olive green, characteristic of other laminated sequences from Holes $679 \mathrm{C}$ and $684 \mathrm{C}$. In contrast, solvent-extracted sediments from Unit II are light gray and contain a higher proportion of fine-grained sand and silt. Concentrations of carotenoids in Unit I are high and uniform, with no significant decrease with depth. Pigment concentrations in Unit II are low and variable, from not detectable in Core 112-681C-7H-2 and $-9 \mathrm{H}-4$, to $6.7 \mu \mathrm{g} / \mathrm{gdw} \beta$-carotene in Core $112-681 \mathrm{C}-10 \mathrm{H}-3$. A sharp decrease in the concentration of $\beta$-carotene and phytoplankton-derived carotenoids, from 30.9 to $6.7 \mu \mathrm{g} / \mathrm{gdw}$, was observed between the laminated sequences of Unit I, Core $112-681 \mathrm{C}-4 \mathrm{H}$, and Unit II, Core $112-681 \mathrm{C}-1 \mathrm{OH}$. This may represent the expected decrease over $20 \mathrm{My}$ in $\beta$ carotene as observed in sediments from Hole $679 \mathrm{C}$. The absence of carotenoids in Cores $112-681 \mathrm{C}-5 \mathrm{H}$ to $-9 \mathrm{H}$ is consistent with the deposition of these sediments under paleooxic conditions. Alternatively, Cores $112-681 \mathrm{C}-5 \mathrm{H}$ to $-9 \mathrm{H}$ 
Table 2. Concentrations of $\boldsymbol{\beta}$-carotene, astaxanthin, canthaxanthin, and diatoxanthin.

\begin{tabular}{|c|c|c|c|c|}
\hline \multirow[b]{2}{*}{ Core } & \multicolumn{4}{|c|}{ Concentrations ( $\mu \mathrm{g} / \mathrm{gdw})$} \\
\hline & $\beta$-carotene & Astaxanthin & Canthaxanthin & Diatoxanthin \\
\hline $112-679 \mathrm{C}-2 \mathrm{H}$ & 28.0 & 2.1 & 1.7 & 1.5 \\
\hline$-3 \mathrm{H}$ & 30.4 & 3.2 & 2.2 & 1.34 \\
\hline$-4 \mathrm{H}$ & 6.5 & 1.5 & 0.9 & 0.83 \\
\hline$-5 \mathrm{H}$ & 13.6 & 3.6 & 2.2 & 0.96 \\
\hline$-6 \mathrm{H}$ & 8.0 & 9.1 & 4.7 & ND \\
\hline$-7 \mathrm{H}$ & 1.3 & 1.1 & 0.6 & 0.14 \\
\hline$-8 \mathrm{H}$ & 1.3 & 1.6 & 0.6 & ND \\
\hline $112-681 \mathrm{C}-1 \mathrm{H}$ & 54.1 & & $\operatorname{tr}$ & \\
\hline$-2 \mathrm{H}$ & 45.4 & 0.4 & ND & 0.18 \\
\hline$-3 \mathrm{H}$ & 57.4 & 2.8 & 0.66 & 1.1 \\
\hline$-4 \mathrm{H}$ & 30.9 & 0.26 & 0.14 & ND \\
\hline$-5 \mathrm{H}$ & 0.9 & 0.19 & 0.04 & 0.02 \\
\hline$-7 \mathrm{H}$ & ND & & & \\
\hline$-9 \mathrm{H}$ & ND & & & \\
\hline$-10 \mathrm{H}$ & 0.67 & 0.62 & 0.11 & ND \\
\hline $112-684 \mathrm{C}-1 \mathrm{H}$ & 48.2 & 12.9 & 6.0 & 19.0 \\
\hline$-12 \mathrm{X}$ & 0.12 & 5.4 & 0.6 & 5.4 \\
\hline
\end{tabular}

$\mathrm{ND}=$ not detected; $\mathrm{tr}=$ trace<smiles>[R]C1CC(C)=C(/C=C/C(C)=C/C=C/C(C)=C/C=C/C=C(C)/C=C/C=C(C)/C(C)=C/C2=C(C)C(C)CC([R])C2(C)C)C(C)(C)C1</smiles><smiles>CC1=C(/C=C/C(C)=C/C=C/C(C)=C/C=C/C=C(C)/C=C/C=C(C)/C=C/C23OC2(C)CCCC3(C)C)C(C)(C)CCC1</smiles>

B-Carotene 5,6-Epoxide<smiles>CC1=C2/C=C/C(C)=C/C=C/C(C)=C/C=C/C=C(C)/C=C/C=C(\C)C(C=C3C(C)(C)CCCC3(C)C)C(C)(CCC1)O2</smiles><smiles>[R]C1CC(C)(C)C(/C=C/C(C)=C/C=C/C(C)=C/C=C/C=C(C)/C=C/C=C(C)/C=C/C2=C(C)C(=O)C([R])CC2(C)C)=C(C)C1=O</smiles>

Figure 1. Structure of carotenoids discussed in text.

represent the zone of intense methanogenesis at this site, which may be linked to the saturation and removal of carotenoids in these sections (Repeta, 1989). Concentrations of 4,4'-dioxo-carotenoids (astaxanthin, canthaxanthin) showed little or no systematic decrease with depth (Table 2). Values ranged from not detectable in bioturbated sequences to 4.4 $\mu \mathrm{g} / \mathrm{gdw}$ astaxanthin in Core $112-681 \mathrm{C}-2 \mathrm{H}$.

Sediments from Hole $684 \mathrm{C}$ lie at $426.5 \mathrm{~m}$ below sea level, within the contemporary oxygen-minimum zone. Both samples from Cores $112-684 \mathrm{C}-1 \mathrm{H}$ and $-12 \mathrm{X}$ were deposited under hemipelagic upwelling conditions. The distribution of carotenoids in sample Core $112-684 \mathrm{C}-1 \mathrm{H}$ is dominated by pigments characteristic of diatoms: $\beta$-carotene, diatoxanthin, and<smiles>CC1=CC(O)CC(C)(C)C1/C=C/C(C)=C/C=C/C(C)=C/C=C/C=C(C)/C=C/C=C(C)/C=C/C1=C(C)CC(O)CC1(C)C</smiles><smiles>COC(C)(C)C(=O)/C=C/C(C)=C/C=C/C(C)=C/C=C/C(C)=C/C=C/C=C(C)/C=C/C=C(\C)CCC=C(C)CCC=C(C)C</smiles><smiles>CC1(C)C[C@H](O)C[C@]2(C)OC(=O)C=C12</smiles><smiles>CC1(C)C[C@H](O)C[C@]2(C)OC(=O)C=C12</smiles><smiles>CC1(C)CCCC2(C)OC(=O)C=C12</smiles>

Dihydroactinidiolide zeaxanthin/lutein. Low concentrations of astaxanthin, canthaxanthin, and $\beta$-carotene epoxides are also present (Fig. 4). The distribution of carotenoids in Core $112-684 \mathrm{C}-12 \mathrm{X}$ is relatively simple. Only low concentrations of $\beta$-carotene and $\beta$-carotene epoxides are present. Major carotenoids include astaxanthin, canthaxanthin, and a mixture of two co-eluting pigments (Fig. 4). Partial deconvolution of the visible spectrum of the pigment mixture suggests at least one component is an acyclic xanthophyll. The concentrations of astaxanthin and canthaxanthin are similar to the concentrations of these pigments in Core $112-681 \mathrm{C}-1 \mathrm{H}$, suggesting little degradation of these pigments over the $20 \mathrm{~m}$.y. represented by these two samples. 
Table 3. Visible and mass spectral data for carotenoids isolated from Leg 112 sediments.

\begin{tabular}{lll}
\hline \multicolumn{1}{c}{ Carotenoid } & \multicolumn{1}{c}{$\lambda_{\max }{ }^{\mathrm{a}}$} & \multicolumn{1}{c}{ Major fragment ions } \\
\hline Astaxanthin & 480 & $(\mathrm{M}+1) 597$ \\
$\beta$-Carotene (all-trans) & $478,452,(420)$ & $(\mathrm{M}+1) 537$ \\
$\beta$-Carotene (cis) & $472,446,(416)$ & $(\mathrm{M}+1) 537$ \\
$\beta$-Carotene 5,6 -epoxide & $468,446,(420)$ & $(\mathrm{M}+1) 553$ \\
$\beta$-Carotene $5,5^{\prime}, 6,6^{\prime}$-diepoxide & $464,436,408$ & $(\mathrm{M}+1) 569$ \\
$\beta$-Carotene 5,8-furanoxide & $454,428,(407)$ & $(\mathrm{M}+1) 553$ \\
Canthaxanthin & 476 & $(\mathrm{M}+1) 565$ \\
Diatoxanthin & $472,446,(420)$ & $(\mathrm{M}+1) 567,(\mathrm{M}+1-18) 549$ \\
Spheroidenone & $(510), 480,(460)$ & $(\mathrm{M}+1) 583,(\mathrm{M}+1-32) 551$ \\
Zeaxanthin/lutein & $476,452,(416)$ & $(\mathrm{M}+1) 569,(\mathrm{M}+1-18) 551$ \\
\hline
\end{tabular}

a Determined online in HPLC effluent.

Quantitatively, these results agree with the general degradation pathway for carotenoids in anoxic marine sediments outlined by Repeta (1989). Using this scheme, caroteno5,6-epoxides should be rapidly degraded by rearrangement to their corresponding 5,8-furanoxides, which undergo subsequent fragmentation to loliolide. $\beta$-carotene, caroteno-3,3'diols (diatoxanthin, zeaxanthin), and structurally related pigments should be degraded by a parallel sequence of transformation reactions after an initial epoxidation step. In the anoxic marine sediments of the Peru margin, epoxidation has been by slow fermentative-type reactions and thus is ratelimiting, allowing $\beta$-carotene, diatoxanthin, and structurally related pigments to persist relative to the more abundant caroteno-5,6-epoxides (fucoxanthin, peridinin, diadinoxanthin).

All samples contain low concentrations of carotene monoepoxides and diepoxides, and rearranged carotene-5,8-furanoxide, as evidenced by visible and mass spectral data $(\beta$ carotene 5,6-epoxide: $\lambda_{\max } 472,444,418 \mathrm{~nm}[\mathrm{M}+1] 553 ; \beta$ carotene 5,5'6,6'-epoxide: $\lambda_{\max } 466,438,414 \mathrm{~nm},[\mathrm{M}+1] 569$; $\beta$-carotene 5,8 furanoxide: $\lambda_{\max } 454,428,(407) \mathrm{nm},[\mathrm{M}+1]$ $553)$. These pigments were not observed in surface sediments and may represent transient intermediates in the degradation of $\beta$-carotene to dihydroactinidiolide (Klok et al., 1984a, 1984 b). In deep samples that do not contain $\beta$-carotene, no $\beta$-carotene epoxides can be seen. Carotenols structurally related to $\beta$-carotene (zeaxanthin and diatoxanthin) should be degraded by a parallel set of transformation reactions to loliolide and isololiolide, at approximately the same rate. Here, analyses demonstrate that this is not the case. Concentrations of diatoxanthin in surface sediments from $11^{\circ}$ and $15^{\circ} \mathrm{S}$ are approximately equal to $\beta$-carotene at the respective locations (Repeta, 1989). In all our samples except the shallowest one from Site 684 , diatoxanthin is $<5 \%$ of the concentration of $\beta$-carotene. In Sample 118-684C-1H-3, the concentration of diatoxanthin is approximately equal to $\beta$-carotene $(50 \mu \mathrm{g} /$ $\mathrm{gdw}$, which is typical of surface sediments. However, concentrations of diatoxanthin rapidly decrease to nondetectable levels. Similar low abundances were observed for zeaxanthin/ lutein. At present we have no explanation for the observed difference in degradation rate between $\beta$-carotene and the carotenols. However, our results are in agreement with the distribution of carotenoids in ancient sediments recovered by the Deep Sea Drilling Program from the Cariaco Trench (Watts and Maxwell, 1977) and with the observed high values of isololiolide in recent sediments from the Namibian shelf (Klok et al., 1984a).

Four classes of carotenoids cannot degrade through furanoxide intermediates to loliolide, isololiolide, or dihydroactinidiolide: 4,4'-dioxo-carotenoids (astaxanthin, canthaxanthin), acyclic carotenoids (spheroidenone), diacetylenic caro- tenoids (alloxanthin), and aromatic carotenoids (renieratene). No aromatic carotenoids have been reported in Peru sediments, however 4,4'-dioxo-carotenoids are abundant. Data from Table 2 demonstrate that the concentration of $4,4^{\prime}$ dioxo-carotenoids is not significantly lower in Pleistocene and Miocene sediments than in recent sediments. A similar result was reported by Watts and Maxwell (1977), who observed good preservation of canthaxanthin and the acyclic carotenoid spheroidenone, in Pleistocene sediments from the Cariaco Trench. We suggest that the observed stability of $4,4^{\prime}$-dioxocarotenoids in sediments is a result of their molecular structure. The good preservation of these pigments in unconsolidated sediments may permit semiquantitative estimates of the zooplankton influx into sediments. The concentration of astaxanthin in zooplankton from the upwelling area averages 2 $\mathrm{mg} / \mathrm{gdw}$ (Repeta and Gagosian, 1984). From values of 2 to 9 $\mu \mathrm{g} / \mathrm{gdw}$ astaxanthin in Hole $679 \mathrm{C}$, we calculated a contribution of between 1 and $5 \mathrm{mg} / \mathrm{gdw}$ zooplankton to these sediments.

\section{CONCLUSIONS}

Carotenoids in the organic-rich sediments sampled during Leg 112 qualitatively record the major sources of organic matter in the upwelling region, with contributions from diatoms, crustaceans, and photosynthetic bacteria. High pigment concentrations were observed in sediments deposited near the center of the oxygen-minimum zone, with downcore abundances reflecting a combination of diagenesis and depositional changes caused by bottom-water oxicity. Carotenoids were observed in highest concentration in laminated muds deposited under dysaerobic conditions. Very low to nondetectable levels of carotenoids were observed in bioturbated sequences deposited during periods of high bottom-water oxygen, coincident with fluctuations in sea level. The most abundant pigment in the youngest sediments from all cores is $\beta$ carotene. $\beta$-carotene slowly degrades to 5,6-epoxide followed by rearrangement to furanoxide. Subsequent fragmentation to dihydroactinidiolide is suggested by the results of Klok et al. (1984a) and is supported here by the low steady-state concentrations of furanoxide intermediates that persist in all our samples until $\beta$-carotene was completely degraded. Little or no degradation of 4,4'-dioxo-carotenoids was observed over the $20 \mathrm{~m}$.y. interval of deposition covered by our samples, which is consistent with the inability of these compounds to form 5,6-epoxides.

\section{ACKNOWLEDGMENTS}

Financial support was provided by National Science Foundation Grant OCE83-10004. I also acknowledgment the donors of the Petroleum Research Fund, administered by the American Chemical Society, for partial support of this work. 


\section{REFERENCES}

Baker, E. W., and Louda, J. W., 1982. Geochemistry of tetrapyrrole, tetraterpenoid, and perylene pigments in sediments from the Gulf of California: Deep Sea Drilling Project Leg 64, Sites 474, 477, 479, and 481 , and Scripps Institution of Oceanography Guaymas Basin Survey Cruise Leg 3, Sites IOG and 18G. In Curry, J. R., Moore, D. G., et al., Init. Repts. DSDP, 64: Washington (U.S. Govt. Printing Office), 789-814.

Boon, J. J., Hines, H., Burlingame, A. L., Klok, J., Rijpsta, W.I.C., deLeeuw, J. W., Edmunds, K. E., and Eglinton, G., 1983. Organic geochemical studies of solar lake laminated cyanobacterial mats. In Bjoroy, H. (Ed.), Advances in Organic Geochemistry 1981: New York (Wiley), 207-227.

Cardoso, J. N., Watts, C. D., Maxwell, J. R., Goodfellow, R., Eglington, G., and Golubic, S., 1978. A biogeochemical study of the Abu Dhabi algae mats: a simplified ecosystem. Chem, Geol., 23:273-291.

Kimble, B. J., Maxwell, J. R., Philip, R. P., Eglinton, G., Albrecht, P., Ensminger, A., Arpino, P., and Ovrisson, G., 1974. Tri- and tetraterpenoid hydrocarbons in the Messel oil shale. Geochim. Cosmochim. Acta, 38:1165-1181.

Klok, J., Baas, M., Cox, H. C., DeLeeuw, J. W., Rijpstra, W.I.C., and Scherick, P. A., 1984a. Qualitative and quantitative characterization of the total organic matter in a recent marine sediment II. In Schenck, P. A. (Ed.), Advances in Organic Geochemistry 1983: New York (Wiley), 265-278.

1984b. Loliolides and dihydroactinidiolides in a recent marine sediment probably indicate a major transformation pathway of carotenoids. Tet. Lett., 5577-5580.

Moore, J. C., 1964. Gel permeation chromatography I. A new method for molecular weight distribution of high polymers. J. Polymer Sci., A2:835-843.

Murphy, M.J.T., McCormich, A., and Eglinton, G., 1967. Perhydro $\beta$-carotene in the Green River shale. Science, 157:1040-1042.

Repeta, D. J., 1989. Carotenoid diagenesis in recent marine sediments. II. Degradation of fucoxanthin to loliolide. Geochim. Cosmochim. Acta, 53:699-707.

Repeta, D. J., and Gagosian, R. B., 1984. Transformation reactions and recycling of carotenoids and chlorins in the Peru upwelling region $\left(15^{\circ} \mathrm{S}, 75^{\circ} \mathrm{W}\right)$. Geochim. Cosmochim. Acta, 48:1265-1277. 1987. Carotenoid diagenesis in recent marine sediments-I. The Peru Continental Shelf $\left(15^{\circ} \mathrm{S}, 75^{\circ} \mathrm{W}\right)$. Geochim. Cosmochim. Acta, 51:1001-1009.

Ridout, P. S., Tibbetts, P.J.C., and Morris, R. J. 1984. Novel carotenoid pigments in organic-rich sediments from the Peru continental shelf. Oceanol. Acta, 7:363-367.

Schwendinger, R. B. 1969. Carotenoids. In Eglinton, G., and Murphy M.J.T. (Eds.), Organic Geochemistry: Methods and Results: New York-Heidelberg-Berlin (Springer-Verlag), 425-437.

Watts, C. D., and Maxwell, J. R. (1977) Carotenoid diagenesis in a marine sediment. Geochim. Cosmochim. Acta, 41:493-497.
Date of initial receipt: 30 October 1988

Date of acceptance: 1 June 1989

Ms 112B-157
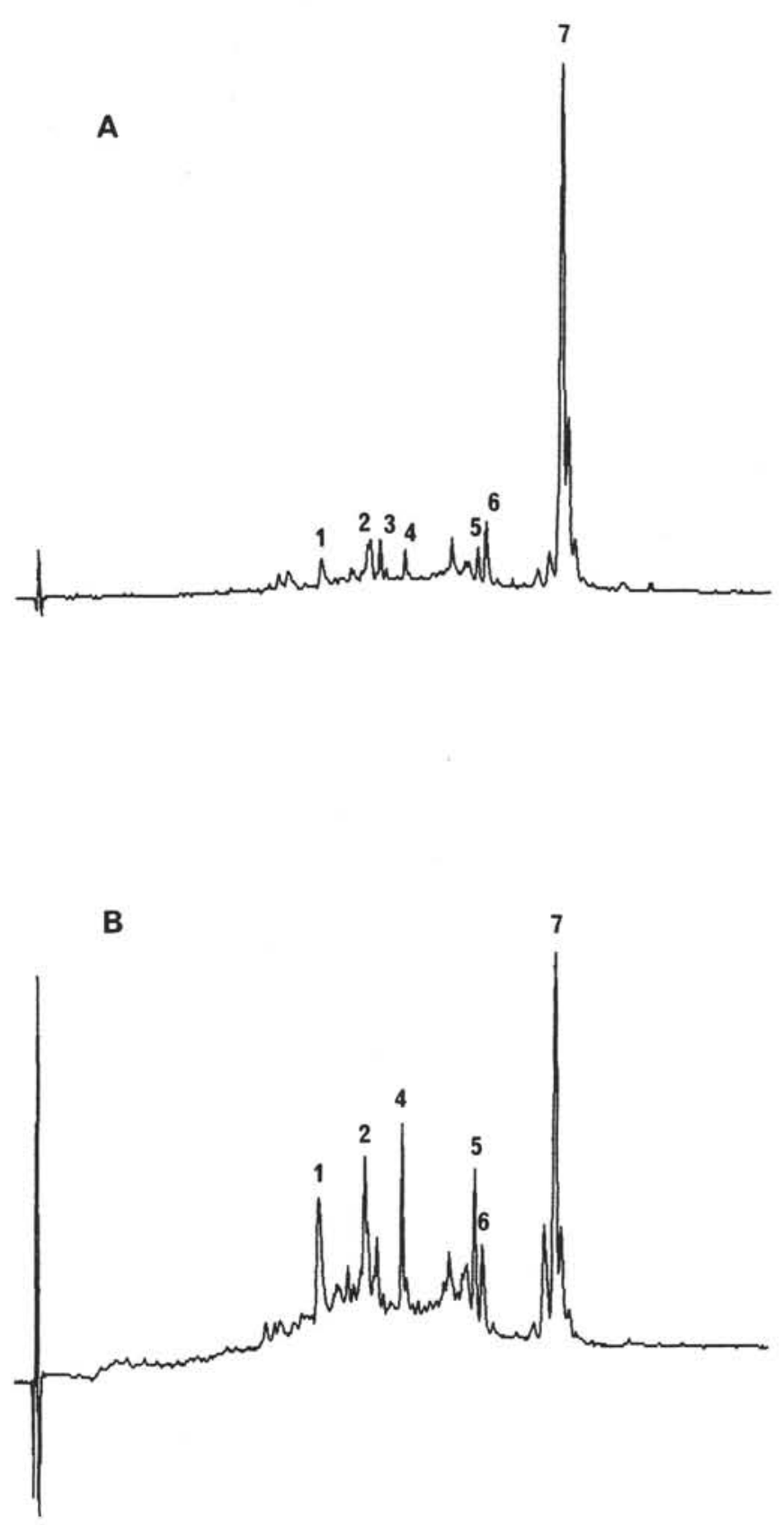

Figure 2. HPLC of carotenoids extracted from sediments of Hole 679C. A. Section 112-679C-3H. B. Section 112-679C-7H. Separation conditions given in text. Detection is at $470 \mathrm{~nm}$. Peak identification is as follows: (1) astaxanthin, (2) diatoxanthin, (3) zeaxanthin/lutein, (4) canthaxanthin, (5) spheroidenone, 6) $\beta$-carotene epoxides/furanoxide and (7) $\beta$-carotene. 
B-Carotene (ug/gdw)

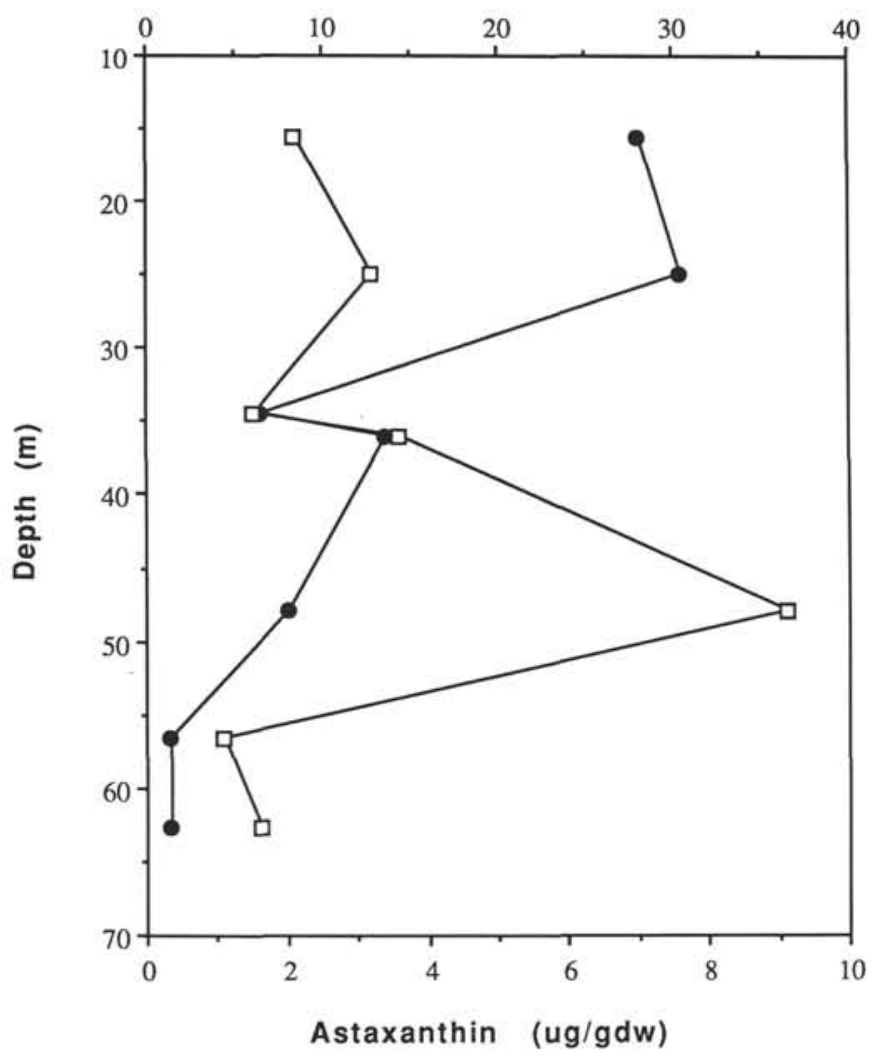

Figure 3. Distribution of astaxanthin (open squares) and $\beta$-carotene (closed circles) in Hole 679C.
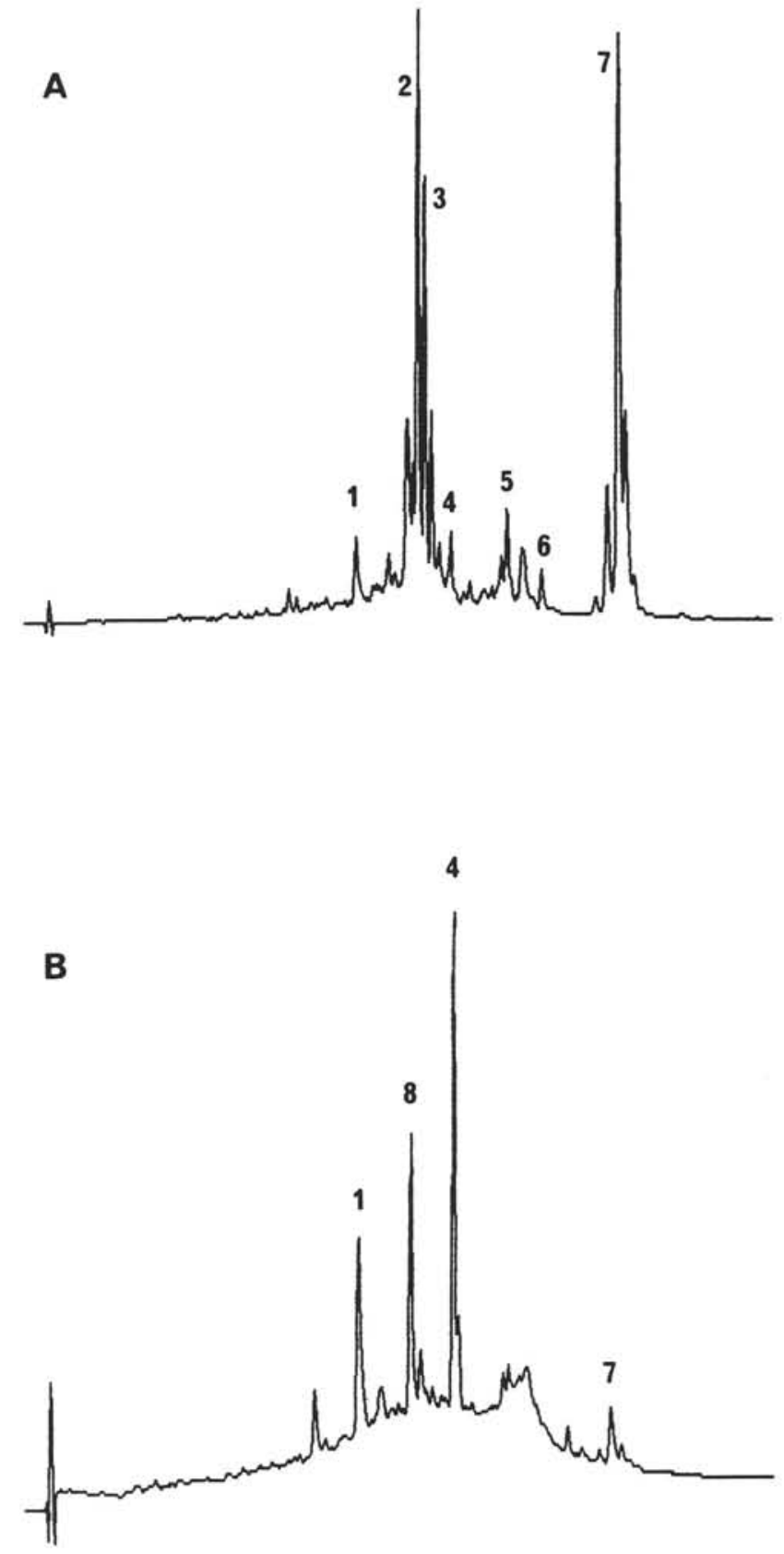

Figure 4. HPLC of carotenoids extracted from sediments of Hole $684 \mathrm{C}$. A. Core $112-684 \mathrm{C}-1 \mathrm{H}$. B. Core 112-684C-12X. Peak identification is as follows: (1) astaxanthin, (2) diatoxanthin, (3) zeaxanthin/ lutein, (4) canthaxanthin, (5) spheroidenone, (6) $\beta$-carotene epoxides/ furanoxides, (7) $\beta$-carotene, and (8) mixture of acyclic xanthophyll and unidentified (bicyclic?) component. 